ECCOMAS

\section{Proceedia}

COMPDYN 2021

$8^{\text {th }}$ ECCOMAS Thematic Conference on Computational Methods in Structural Dynamics and Earthquake Engineering

M. Papadrakakis, M. Fragiadakis (eds.) Streamed from Athens, Greece, 28 - 30 June 2021

\title{
A COMPARATIVE STUDY ON SEISMIC RESPONSE OF A SUPER HIGH-RISE BUILDING USING CONVENTIONAL AND MODAL PUSHOVER ANALYSIS
}

\author{
Xianlong Zhang ${ }^{1}$, Hao $\mathrm{Wu}^{2 *}$, Qiao $\mathrm{Yu}^{2}$, Yang Liu ${ }^{1}$, Lingzhi $\mathbf{L i}^{2}$, \\ Wannan $\mathrm{Xu}^{1}$, Junyan Zhou ${ }^{1}$ \\ ${ }^{1}$ China Construction Seventh Engineering Division (Shanghai) Corp. Ltd. \\ 235 E. Yunling Rd., Putuo District, Shanghai 200062, China \\ 1091370813@qq.com, liuyang10@cscec.com,xuwn@cscec.com,398620137@qq.com \\ ${ }^{2}$ College of Civil Engineering, Tongji University \\ 1239 Siping Rd., Shanghai 200092, China \\ 2009wuhao_tom@tongji.edu.cn,yq@ @tongji.edu.cn, lilingzhi@tongji.edu.cn
}

\begin{abstract}
For super high-rise buildings, higher order modal shapes may have a significant impact on the structural response under seismic excitations. Since conventional pushover analysis procedure only includes the contribution from the first modal response, it is not able to accurately account for the varying dynamic characteristics of a super high-rise building. Based on mode superposition response spectrum method, modal pushover analysis (MPA) procedure is proposed to consider enough number of modes, which improves the conventional pushover analysis procedure to a certain extent. Based on a case-study super high-rise structure, this paper comparatively investigates the seismic responses of the structure using conventional pushover procedure and MPA procedure, and the accuracy of the results are validated through comparison with nonlinear time history analysis. The results show that the MPA procedure has a great improvement in accuracy as compared to the conventional pushover procedure. It is also demonstrated that the calculated structural response from MPA are in very good agreement with the results from nonlinear time history analysis, such as peak story displacements and story forces, while reducing computing time tremendously which improves the efficiency of seismic analysis of super high-rise buildings.
\end{abstract}

Keywords: Super High-Rise Buildings, Modal Pushover Analysis, Nonlinear Time-History Analysis, Seismic Response. 


\section{INTRODUCTION}

The philosophy of seismic design for building structures has been gradually evolved from force-based design to displacement-based and performance-based design during the past decades. Pushover analysis procedure, known as a nonlinear static analysis procedure which could be an alternative to nonlinear time history analysis (NTHA) procedure, has been widely used and adopted within the scope of performance-based design [1]. In spite that the Pushover analysis procedure has the benefits of simplicity and relative accuracy, the fundamental assumptions behind the procedure has limited its use to a certain extent, especially for high-rise structures, which are: 1) the response of the structure is related to a certain equivalent single degree of system (SDOF), and 2) the deformation envelop along the structure height is assumed to maintain constant throughout the entire seismic behavior evolution even for the nonlinear response stage. Obviously, these assumptions have excluded the higher mode responses which should be evident in high-rise and super high-rise structures. For this end, Chopra et al. [2] has proposed a new Pushover analysis procedure, i.e., Modal Pushover Analysis (MPA) procedure, which analyze a structure using Pushover analysis at several selected modes, and combines the modal responses using a certain combination rule to get the final response. Since this procedure is able to include the higher mode responses, it becomes more popular than conventional Pushover analysis for seismic performance assessment of high-rise buildings.

This paper comparatively investigates the seismic response of a case-study super high-rise structure using MPA procedure. Various numbers of modes are selected including only one mode (which becomes traditional Pushover analysis) in order to assess the accuracy of the procedure. The results from MPA are then compared with the results from NTHA to evaluate the accuracy of MPA procedure.

\section{PROCEDURE OF MODAL PUSHOVER ANALYSIS}

A brief introduction to the main process of MPA procedure used in the current study are presented in the following text. More details regarding the theory and any specific attentions that should be paid during analysis could be found in literature [3-6]. The step-by-step illustration of the MPA analysis process are:

1) Step 1: Calculate the structural vibration periods $T_{n}$ and vibration modes $\varphi_{n}$;

2) Step 2: For the $n^{\text {th }}$ vibration mode, establish the base shear versus top displacement relationship (i.e., Pushover curve) based on a constant lateral force distribution $\boldsymbol{s}_{n}^{*}=\boldsymbol{m} \varphi_{n}$;

3) Step 3: Transfer the analyzed Pushover curve to the idealized double broken Pushover curve for the $n^{\text {th }}$ vibration mode, then transfer the idealized curve to the capacity curve (i.e., acceleration versus displacement relationship) for the $n^{\text {th }}$ modal elasto-plastic SDOF system according to the following equations;

$$
\begin{gathered}
\frac{F_{s n y}}{L_{n}}=\frac{V_{b n y}}{M_{n}^{*}} \\
D_{n y}=\frac{u_{r n y}}{\Gamma_{n} \varphi_{r n}}
\end{gathered}
$$

where, $M_{n}^{*}$ is the equivalent modal mass, and $\Gamma_{n}$ is the modal contribution coefficient.

4) Step 4: Calculate the structural responses $r_{n}$ of the $n^{\text {th }}$ vibration mode using elastoplastic response spectrum; 
5) Step 5: Repeat the above Steps 3 and 4 for all the vibration modes determined to use in the MPA analysis;

6) Step 6: Obtain the total seismic demands based on a certain combination rule, such as the square root of sum of squares (SRSS) rule;

$$
r=\sqrt{\sum r_{n}^{2}}
$$

where, $r_{n}$ is the $n^{\text {th }}$ modal seismic demand, and $r$ is total seismic demand.

\section{THE CASE-STUDY SUPER HIGH-RISE BUILDING}

\subsection{Description of the building}

In this study, a super high-rise building is selected as the case-study structure for MPA analysis. Figure 1 shows the typical floor plan of the structure. As shown, the structural system of the building is frame-core wall system, which is the most commonly used system for super high-rise buildings in China. This system combines reinforced concrete (RC) wall cores (in the plan center) and columns (in the perimeter) to resist later loads, thus obtaining the balance between lateral resistance and stiffness along with architectural functions. The frame columns of the building are concrete filled steel tube (CFT) columns, and the frame beams are $\mathrm{RC}$ beams and steel beams. The coupling beams of core walls are steel-concrete coupling beams and RC coupling beams. In order to increase the lateral stiffness, outriggers and megabraces are used at several stories along the building height. The total height of building is 400 $\mathrm{m}$ with 96 stories. Structural concrete strength is C60 based on Chinese design code [7] for columns and core walls, and C35 for floors. The structural steel is Q345, and reinforcing steel is HRB500 for force resisting bars and HRB400 for hoops and stirrups. According to Chinese seismic design code [8], the building is designed for a site of 8 degree representing high seismicity (the peak ground acceleration for design earthquake is $0.2 \mathrm{~g}$ ). The site class is III, and the seismicity group is I, resulting the site characteristic period of $0.45 \mathrm{sec}$. Dead and live loads for both floor and roof stories are $5 \mathrm{kN} / \mathrm{m}^{2}$ and $2 \mathrm{kN} / \mathrm{m}^{2}$, respectively. The design of the building is performed before the analysis of the study using the Chinese structural design software PKPM [9]. A list of the structural member sizes can be referred to as in Table 1 (for horizontal members) and Table 2 (for vertical members).

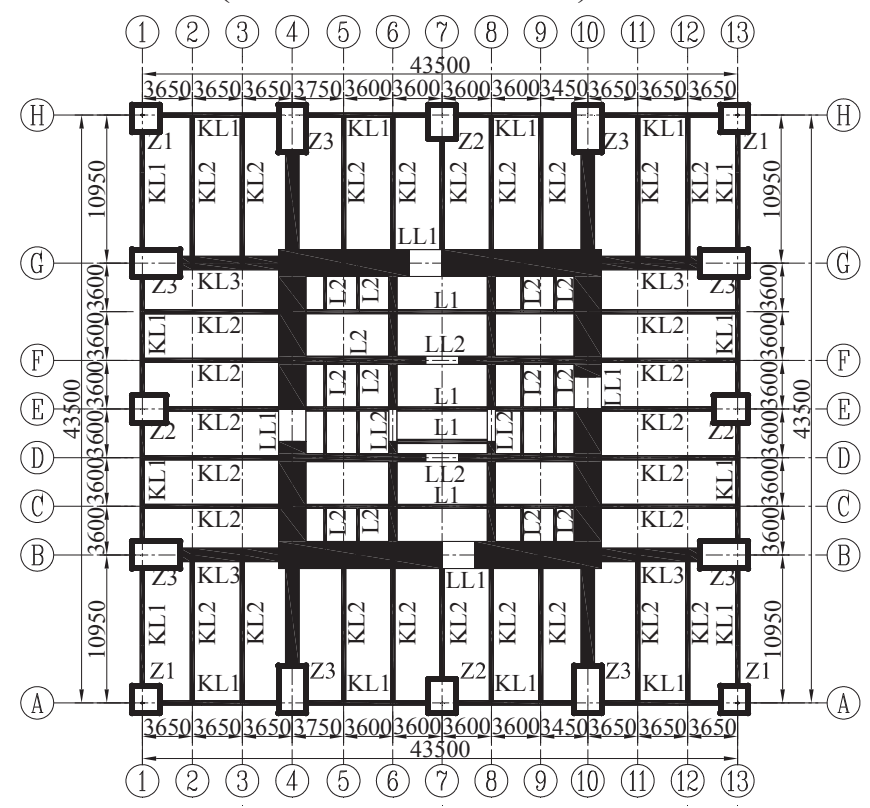

Figure 1: Typical floor plan layout (unit: $\mathrm{mm}$ ). 
X. Zhang, H. Wu, Q. Yu, Y. Liu, L. Li, W. Xu and J. Zhou

\begin{tabular}{|c|c|c|c|c|c|c|c|}
\hline Story & KL1 & KL2 & KL3 & LL1 & LL2 & L1 & $\mathrm{L} 2$ \\
\hline $1 \sim 4$ & & & & $2000 * 2000+1200 * 1200 * 50 * 50$ & & & \\
\hline $5 \sim 14$ & & & & $1800 * 2000+1200 * 1200 * 50 * 50$ & & & \\
\hline $15 \sim 24$ & & & & $1560 * 1000+800 * 800 * 45 * 45$ & $600 * 800$ & & \\
\hline $25 \sim 27$ & & & & $1320 * 1000+800 * 800 * 45 * 45$ & & & \\
\hline $28 \sim 31$ & & $900 * 300$ & $1000 * 1200$ & & & & \\
\hline $31 \sim 37$ & & $* 25 * 40$ & & $1080 * 1000+800 * 400 * 50 * 55$ & & & \\
\hline $38 \sim 40$ & $1000 * 300$ & & & $1320 * 1000$ & & & \\
\hline $41 \sim 50$ & $* 28 * 40$ & & & $1080 * 1000+800 * 400 * 50 * 55$ & & $300 * 700$ & $200 * 350$ \\
\hline $51 \sim 53$ & & & & $1080 * 1000$ & & & \\
\hline $54 \sim 72$ & & & $800 * 1000$ & $800 * 1000+600 * 300 * 40 * 45$ & $400 * 800$ & & \\
\hline $73 \sim 75$ & & $\begin{array}{c}650 * 300 \\
* 14 * 30\end{array}$ & & & & & \\
\hline $76 \sim 86$ & & $\begin{array}{c}900 * 300 \\
* 25 * 40\end{array}$ & & $600 * 800$ & & & \\
\hline $\begin{array}{c}87 \sim 95 \\
96\end{array}$ & $\begin{array}{c}700 * 300 * \\
16 * 30\end{array}$ & \multicolumn{2}{|c|}{$650 * 300 * 14 * 30$} & $300 * 600$ & & \multicolumn{2}{|c|}{$300 * 700$} \\
\hline
\end{tabular}

Note: 1) The meaning of section size of I-beam is height*width*thickness of web*thickness of flange. 2) The meaning of section size of steel reinforcement concrete beam is section size of full section + section size of I-beam.

Table 1: Horizontal members'section size (Unit: $\mathrm{mm}$ ).

\begin{tabular}{|c|c|c|c|c|c|c|c|}
\hline Story & Z1 & $\mathrm{Z} 2$ & $\mathrm{Z3}$ & $\begin{array}{l}\text { Inner } \\
\text { wall }\end{array}$ & $\begin{array}{l}\text { Exterior } \\
\text { wall }\end{array}$ & Truss & Brace \\
\hline $1 \sim 4$ & & & & \multirow{9}{*}{600} & 2000 & - & $800 * 800 * 55 * 55$ \\
\hline $5 \sim 11$ & & & & & & - & $800 * 800 * 25 \pi 57$ \\
\hline $12 \sim 14$ & & & & & 1800 & $700 * 700 * 50 * 50$ & - \\
\hline $15 \sim 24$ & $2000 * 2000$ & $2000 * 3500 *$ & $2000 * 3500 *$ & & 1560 & - & $1000 * 1000 * 60 * 60$ \\
\hline $25 \sim 27$ & $* 70 * 70$ & $70 * 70$ & $70 * 80$ & & 1320 & $700 * 700 * 50 * 50$ & - \\
\hline $28 \sim 37$ & & & & & & - & $1000 * 1000 * 60 * 60$ \\
\hline $38 \sim 40$ & & & & & 1080 & $700 * 700 * 50 * 50$ & - \\
\hline $41 \sim 50$ & & & & & 1080 & - & $1000 * 1000 * 60 * 60$ \\
\hline $51 \sim 53$ & & & & & & $700 * 700 * 50 * 50$ & - \\
\hline $\begin{array}{l}54 \sim 66 \\
67 \sim 72\end{array}$ & $1500 * 1500$ & $1500 * 2000$ & $1500 * 3000$ & \multirow[b]{2}{*}{400} & 800 & - & $1000 * 1000 * 60 * 60$ \\
\hline $73 \sim 75$ & $1200 * 1200$ & $1200 * 1600$ & $1200 * 2000$ & & 600 & $\begin{array}{l}700 * 700 * 50 * 50 \\
500 * 500 * 30 * 30\end{array}$ & - \\
\hline $76 \sim 86$ & $1000 * 1000$ & $1000 * 1200$ & $1000 * 1800$ & 300 & 600 & - & $900 * 1300 * 100 * 50$ \\
\hline $87 \sim 89$ & & & & & & $500 * 500 * 30 * 30$ & \\
\hline $\begin{array}{c}90 \sim 95 \\
96\end{array}$ & $500 * 500$ & $500 * 800$ & \multicolumn{2}{|c|}{$650 * 1000$} & 300 & - & - \\
\hline
\end{tabular}

Note: 1) The meaning of section size of CFT column is height*width*thickness of steel plate in height direction*thickness of steel plate in width direction. 2) The rectangular steel tube is used for truss and brace, and the meaning of section size is height*width*thickness of steel plate in height direction*thickness of steel plate in width direction.

Table 2: Vertical members' section size (Unit: mm).

\subsection{Numerical modeling}

To conduct the MPA nonlinear static analysis, the numerical model of the case-study building is established using PERFORM-3D software [10]. The building core walls are modeled using General Wall element in PERFORM-3D, considering both the axial-flexural interaction as well as nonlinear shear behavior. The axial and flexural behavior of the core walls are modeled using fiber-section-based models, while the shear behavior is modeled by defining shear material in PERFORM-3D. The CFT columns are modeled using fiber section beam-column element, which similarly is capable to simulate the axial-flexural interaction 
behavior of the columns. For simplicity, all the beams are modeled using concentrated plasticity beam-column element, and the moment-curvature constitutive relationship for the concentrated plastic hinge in the element could be determined based on the static elasto-plastic method. For coupling beams, it is critical to include shear effect in the element to model shear mechanism of coupling beams. All the material models are determined according to current design codes as well as several reference guidelines [7, 8, 11-14]. Figure 2 shows the elevation view of the considered super high-rise building model. Note that, this building model is analyzed only through only one of the horizontal directions (the X-direction) in the following text for simplicity. Table 3 shows the comparison of the first fifth modal period results (in Xdirection) from both PERFORM-3D and PKPM, which indicates good agreement between different analytical software.

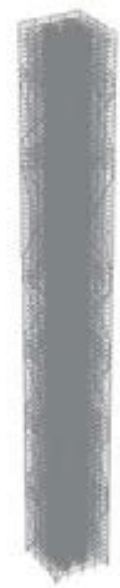

(a) Three-dimensional view

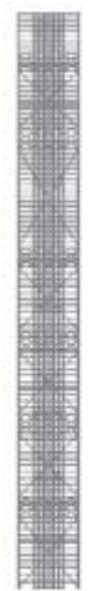

(b) X-direction view

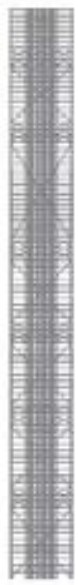

(c) Y-direction view

Figure 2: Elevation view of the building model.

\begin{tabular}{cccc}
\hline Mode (X-direction) & PKPM & Perform-3D & Error \\
\hline 1 & 6.025 & 5.999 & $0.43 \%$ \\
4 & 1.615 & 1.569 & $2.85 \%$ \\
7 & 0.792 & 0.762 & $3.84 \%$ \\
10 & 0.518 & 0.493 & $4.73 \%$ \\
14 & 0.374 & 0.352 & $5.76 \%$ \\
\hline
\end{tabular}

Table 3: Modal analysis results in X-direction.

\section{GROUND MOTION DATA}

For nonlinear time history analysis, a total of five ground motions are selected in the current study, including four recorded natural seismic excitations from PEER ground motion database, and one artificial ground motion. Table 4 presents the basic information for the five earthquake ground motions, including earthquake records' site station, year and duration time. Figure 3 a shows the design spectrum with $5 \%$ damping ratio based on Chines seismic design code [8] along with the individual ground motion spectrum. Figure $3 \mathrm{~b}$ shows the comparison of the average ground motion spectrum with the design spectrum. It can be referred from the figure that the average spectrum of the ground motions matches well with the design spectrum in an overall sense. 


\begin{tabular}{cccc}
\hline Number & Station & Year & Duration Time (s) \\
\hline User_1 & - & - & 43 \\
RSN721 & $\begin{array}{c}\text { El Centro Imp. } \\
\text { Co. Cent }\end{array}$ & 1987 & 59 \\
RSN728 & $\begin{array}{c}\text { Westmorland Fire } \\
\text { Station }\end{array}$ & 1987 & 52 \\
RSN5823 & Chihuahua Station & 2010 & 83 \\
RSN5977 & Chihuahua Station & 2010 & 51 \\
\hline
\end{tabular}

Table 4: Ground motion data.

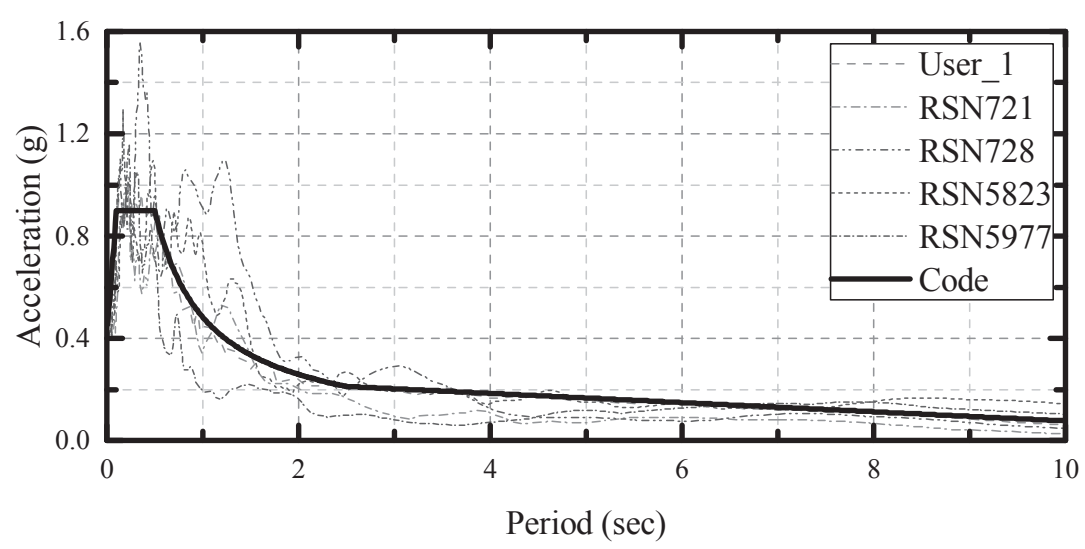

(a) Acceleration response spectrum of ground motions.

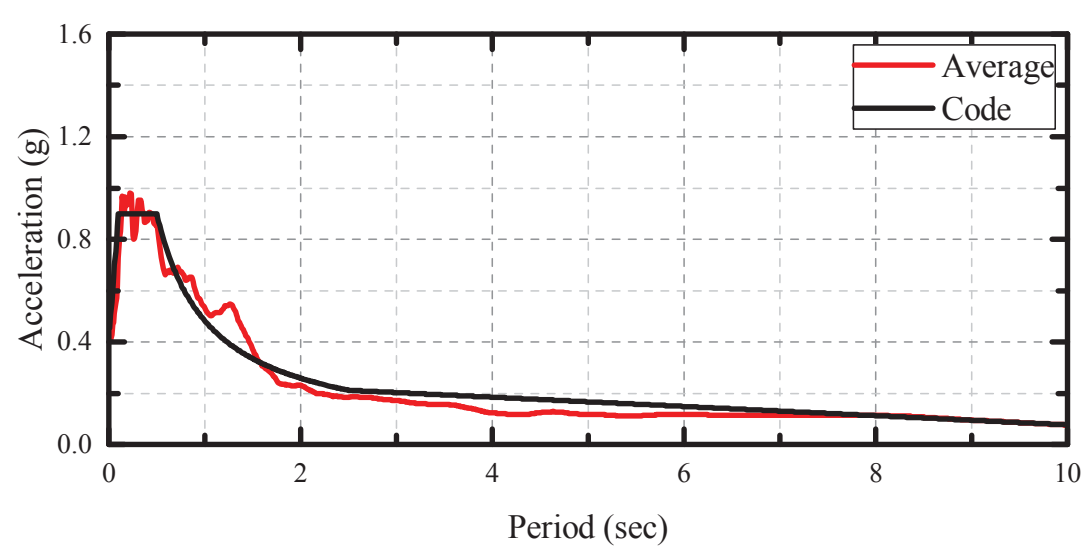

(b) Average acceleration response curve of ground motions.

Figure 3: Response spectrum of the ground motions.

\section{SEISMIC RESPONSE RESULTS}

\subsection{Pushover curves}

In this section, seismic analysis results for the case-study building from the MPA analysis and its comparison with traditional Pushover analysis (i.e., use the first mode for MPA only) are presented. As mentioned, the accuracy of the MPA results is assessed through comparison with results from nonlinear time history analysis. As per MPA process illustrated earlier, the building model is subjected to a specific lateral force distribution (i.e., modal force distribution) first, then the static pushover analysis is conducted for each mode, respectively. Since the aim of the current study is to demonstrate the accuracy of the MPA procedure rather than 
seismic performance assessment, only the vibration modes in the X-direction are considered. The maximum number of modes in X-direction considered in the current MPA analysis is five. Figure 4 shows the Pushover curves, i.e., base shear versus roof displacement relationships for all the five modal responses. Since the equivalent SDOF system with larger vibration period has less lateral stiffness, the pushover curve tends to be more flexible (larger displacement). Each pushover curve is then transferred to the capacity curves and is used to compare with the demand curve (also transferred from response spectrum as in Section 2) in order to determine the "Performance point". In this case, the seismic intensity is selected to be the design earthquake level, i.e., 8 degree seismicity $(\mathrm{PGA}=0.2 \mathrm{~g})$. Once the "Performance point" for each mode has been determined, the total response of the structure using MPA could be easily determined through SRSS combination rule.
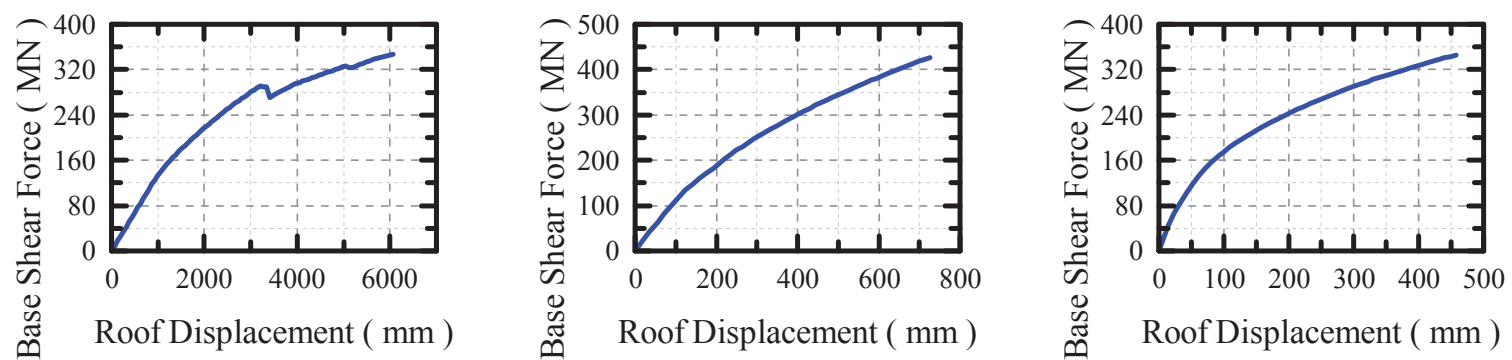

(a) Mode 1 (mode 1 in X-direction)

(b) Mode 4 (mode 2 in X-direction)

(c) Mode 7 (mode 3 in X-direction)

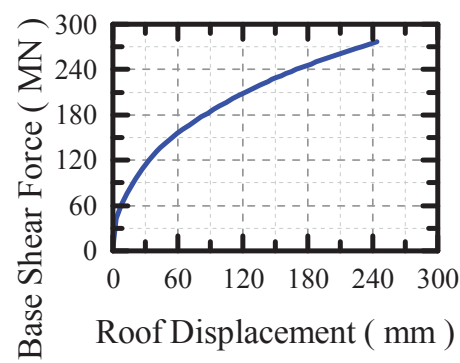

(d) Mode 10 (mode 4 in X-direction)

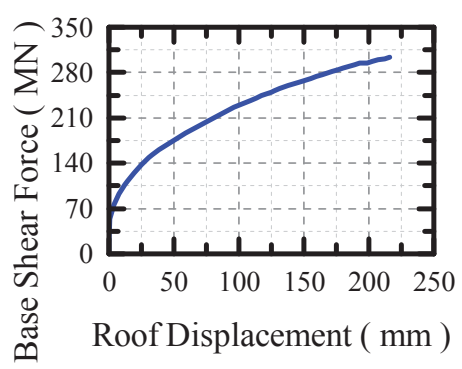

(e) Mode 14 (mode 5 in X-direction)

Figure 4: Pushover curves.

\subsection{Story drifts and peak displacements}

Figure 5 and Figure 6 show the story drift response and peak story response along the building height from both the MPA and NTHA analysis results. The relative error for each MPA results (including one mode to five modes) with NTHA results are also given. It can be seen clearly from the figure, with more modes considered in the MPA results, more accuracy results relative to NTHA response could be achieved. Moreover, for the case-study super high-rise building, all the MPA results show quite good results for those stories under 60 . However, for those stories above 60, MPA results with more than three modes show evidently much better accuracy as compared with MPA results with only two or one (i.e., traditional Pushover analysis) modes considered. Noted that only the X-direction is considered in the analysis, and for the first three modes in X-direction, the total number of modes should be 11 when all the three directions are included. 


\subsection{Story shear forces and overturning moments}

Similarly, Figure 7 and Figure 8 show the story shear force response and story overturning moment response from both the MPA and NTHA analysis results. The relative error for each MPA results (including one mode to five modes) with NTHA results are also given. Similar to the results of story drifts and story displacements presented above, it is referred from the figures that the MPA results with more modes included in the analysis, more accuracy of the results could be achieved relative to NTHA response. For the shear force response, MPA results with 5 modes (blue lines in the figure) shows better accuracy in an overall extent (Figure 7b). However, for overturning moment response, MPA results with 5 modes (blue lines) shows much better results for stories above 25 as compared to results from traditional pushover procedure (i.e., only one mode considered).

\section{CONCLUTIONS}

This study investigates the effects of the Modal Pushover Analysis (MPA) procedure for a case-study super high-rise building, and the accuracy of the MPA results is validated through comparison with NTHA responses. The following conclusions are drawn from the study.

1) Higher mode effects could be included in MPA procedure, which shows the advantage for MPA analysis over traditional Pushover analysis, especially for analyzing high-rise and super high-rise buildings. In this study, the accuracy of MPA is sufficient when more than three modes (in X-direction) are considered in MPA (corresponding to 11 modes when all the three directions are considered).

2) MPA procedure shows a great improvement in accuracy as compared to the conventional pushover procedure (MPA with only one mode considered). It is also demonstrated that the calculated structural response from MPA are in very good agreement with the results from NTHA, in terms of story displacements (and drifts) and story forces (shear force and overturning moment), while reducing computing time tremendously, which in turn improves the efficiency of seismic analysis for super high-rise buildings.
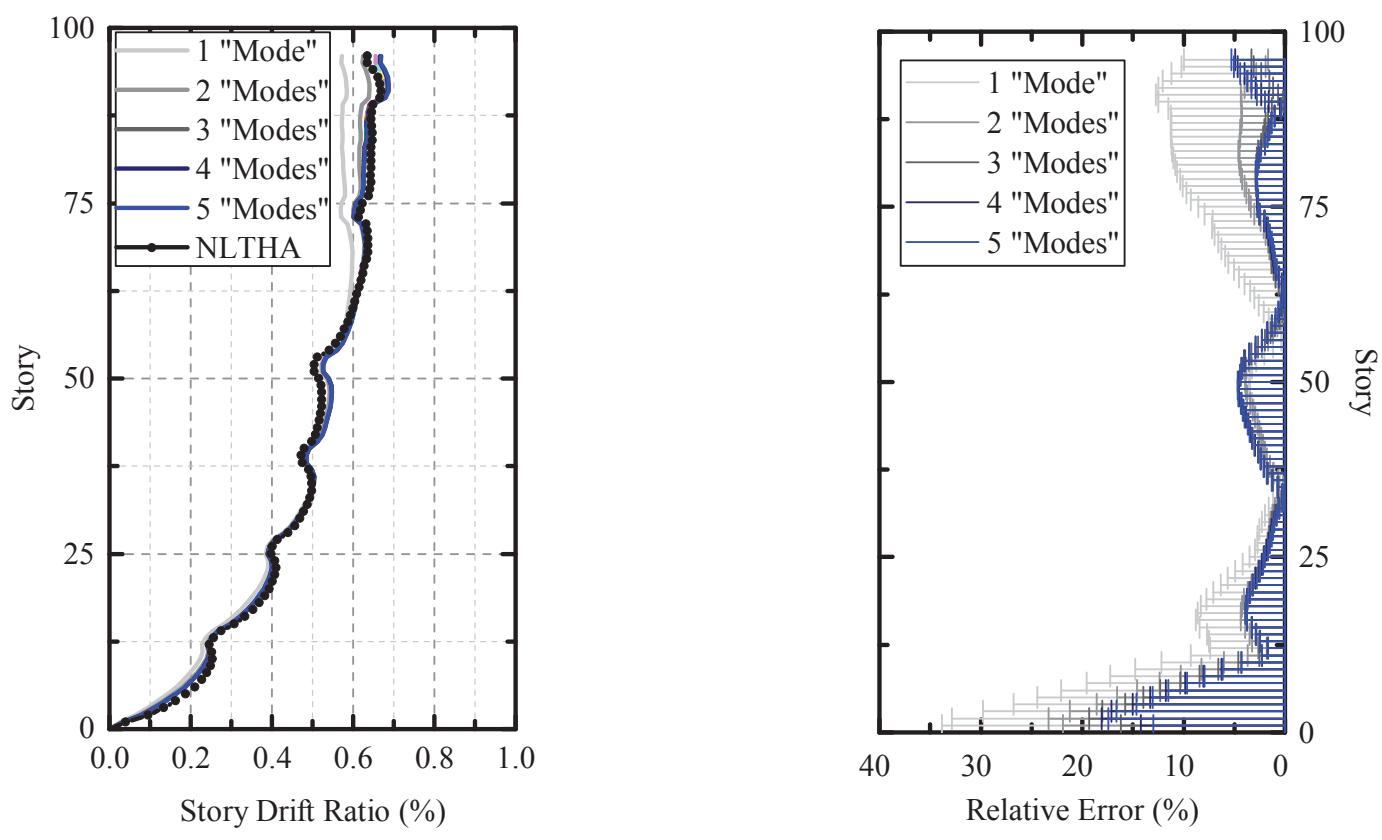

Figure 5: Comparison of the story drift ratios. 

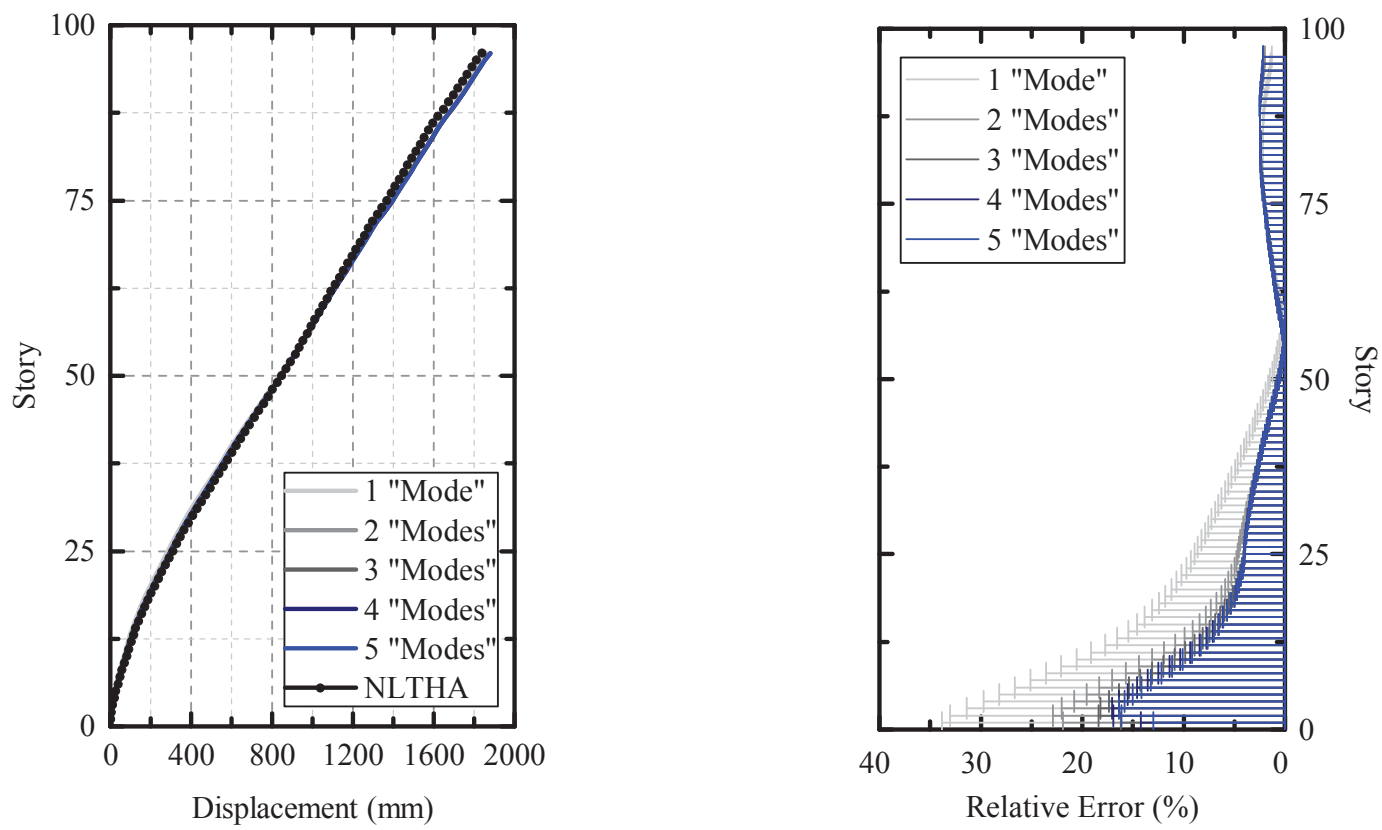

Figure 6: Comparison of the peak story displacements.
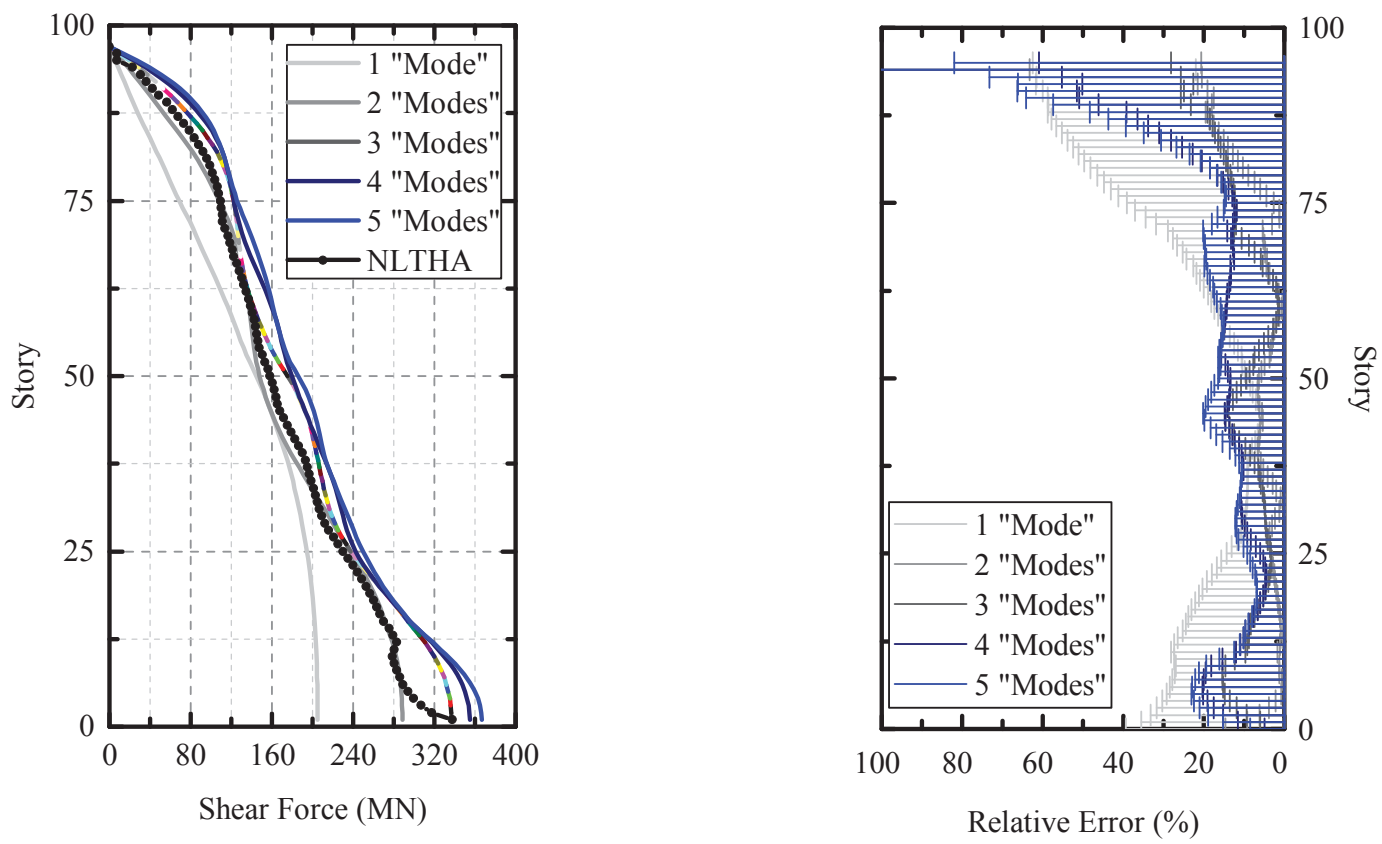

Figure 7: Comparison of the story shear forces. 

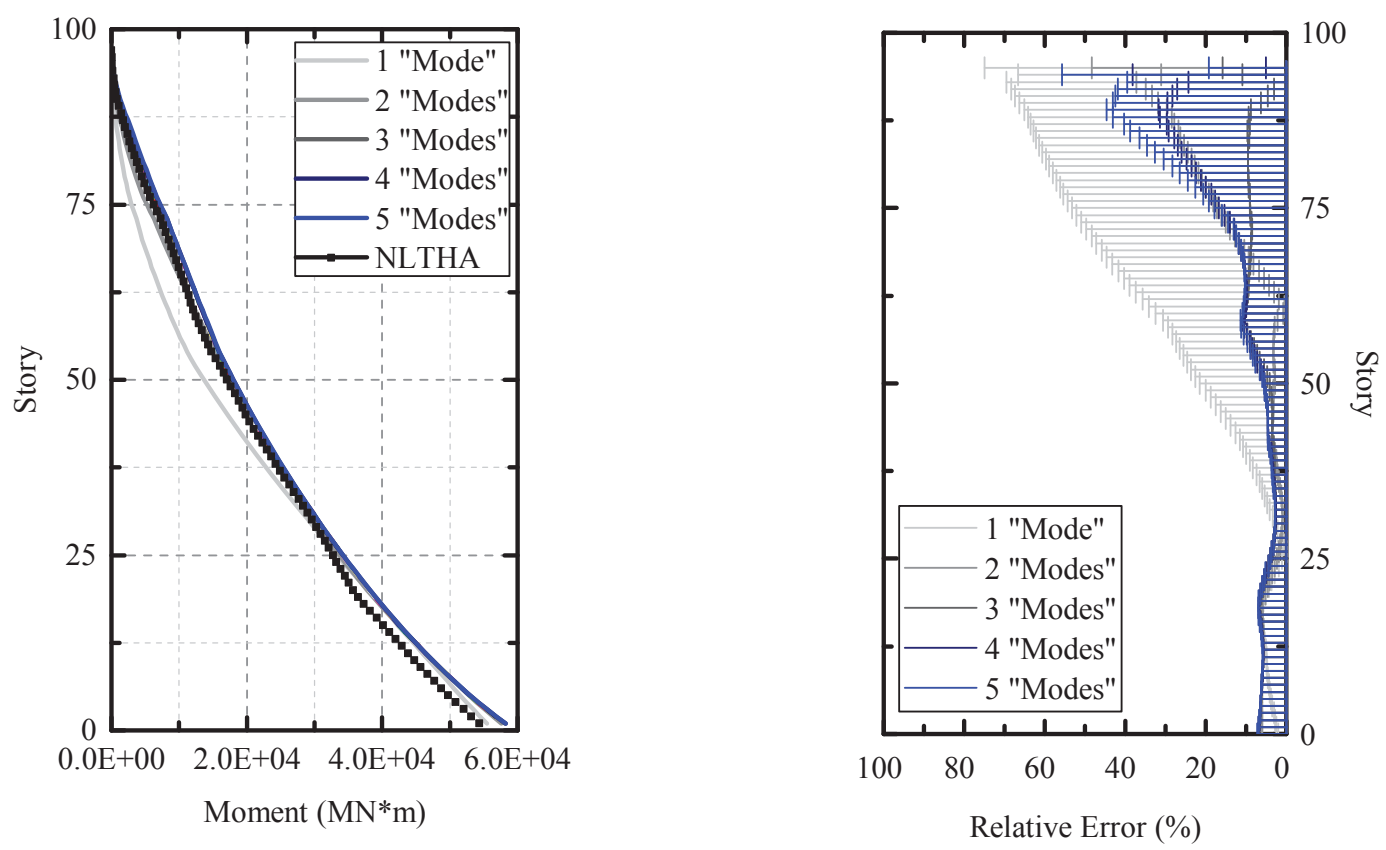

Figure 8: Comparison of the story overturning moments.

\section{REFERENCES}

[1] Building Seismic Safety Council, NEHRP guidelines for the seismic rehabilitation of buildings. FEMA 273, Federal Emergency Management Agency. Washington, D.C., 1997.

[2] A.K. Chopra, R.K. Goel. A modal pushover analysis procedure to estimate seismic demands for buildings: theory and preliminary evaluation [R]. Berkeley, CA: Report No. PEER 2001/03, Pacific Earthquake Engineering Research Center, University of California, 2001.

[3] J. Mao, L. Xie, C. Zhai. Studies on and improvements in modal pushover analysis. Journal of Earthquake Engineering and Engineering Vibration, 26(6): 50-55, 2006. (in Chinese)

[4] P. Shen, H. Gong. Multi-mode pushover analysis and seismic evaluation in hybrid structures. Engineering Mechanics, 23(8), 69-73, 2006. (in Chinese)

[5] Q. Ma, L. Ye, X. Lu. Comparative evaluation of correctness between MPA and pushover analysis. Journal of South China University of Technology: Natural Science Edition, 36(11), 121-128, 2008. (in Chinese)

[6] H. Liu, Q. Guo. Simplified pushover analysis with influence of high-order vibration modes. Journal of Harbin Institute of Technology, 41(10), 188-192, 2009.

[7] GB 50010-2010, Code for design of concrete structures. China Architecture \& Building Press, Beijing, 2015. (in Chinese)

[8] GB 50011-2010, Code for seismic design of buildings. China Architecture \& Building Press, Beijing, 2016. (in Chinese) 
[9] PKPM. User's manual. Version 4, 2011. (in Chinese)

[10] PERFORM-3D. User guide PERFORM-3D ${ }^{\mathrm{TM}}$ nonlinear analysis and performance assessment for 3D structures. Version 7, 2018.

[11] JGJ 138-2016, Code for design of composite structures. China Architecture \& Building Press, Beijing, 2016. (in Chinese)

[12] JGJ 3-2010, Technical specification for concrete structures of tall building. China Architecture \& Building Press, Beijing, 2010. (in Chinese)

[13] GB 50009-2012, Load code for the design of building structures. China Architecture \& Building Press, Beijing, 2012. (in Chinese)

[14] GB 50017-2017, Standard for design of steel structures. China Architecture \& Building Press, Beijing, 2017. (in Chinese) 